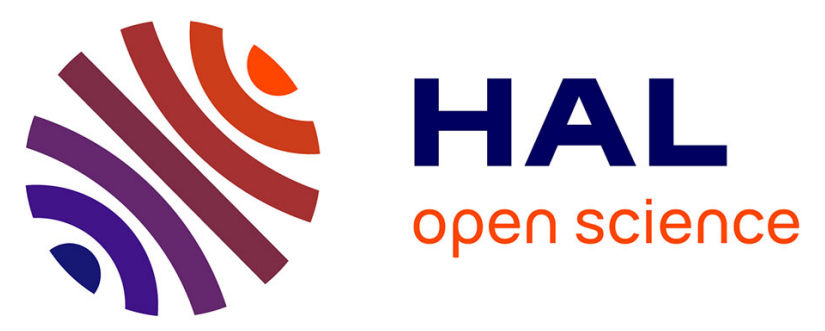

\title{
High external sucrose concentration inhibits the expansion of detached tomato fruits grown in a novel semi-open device
}

Philippe Bussieres, Nadia Bertin, Cindy E. Morris, Christian Vigne, Patrick Orlando, Catherine Glaux, Valérie Sevenier, Hélène Floret, Jean Bernadac, Sylvie Korownikoff

\section{To cite this version:}

Philippe Bussieres, Nadia Bertin, Cindy E. Morris, Christian Vigne, Patrick Orlando, et al.. High external sucrose concentration inhibits the expansion of detached tomato fruits grown in a novel semi-open device. In Vitro Cellular \& Developmental Biology - Plant, 2011, 47 (6), pp.743-751. 10.1007/s11627-011-9378-z . hal-02646721

\section{HAL Id: hal-02646721 \\ https://hal.inrae.fr/hal-02646721}

Submitted on 29 May 2020

HAL is a multi-disciplinary open access archive for the deposit and dissemination of scientific research documents, whether they are published or not. The documents may come from teaching and research institutions in France or abroad, or from public or private research centers.
L'archive ouverte pluridisciplinaire HAL, est destinée au dépôt et à la diffusion de documents scientifiques de niveau recherche, publiés ou non, émanant des établissements d'enseignement et de recherche français ou étrangers, des laboratoires publics ou privés. 
Version définitive du manuscrit publié dans / Final version of the manuscript published in : In Vitro Cellular and Developmental Biology Plant, 2011, Online First, DOI: 10.1007/s11627-011-9378-z

High external sucrose concentration inhibits the expansion of detached tomato fruits grown in a novel semi-open device

Philippe Bussières ${ }^{\mathrm{a},{ }^{*}}$ Nadia Bertin ${ }^{\mathrm{a}}$ Cindy E Morris ${ }^{\mathrm{b}}$ Christian Vigne ${ }^{\mathrm{a}}$ Patrick Orlando ${ }^{\mathrm{a}}$ Catherine Glaux ${ }^{\mathrm{b}}$ Valérie Sévénier ${ }^{\mathrm{a}}$ Hélène Floret ${ }^{\mathrm{a}} \mathrm{Jean}_{\text {Bernadac }}{ }^{\mathrm{a}}$ Sylvie Korownikoff ${ }^{\mathrm{a}}$

${ }^{\mathrm{a}}$ INRA, UR1115 Plantes et Systèmes de culture Horticoles, F-84000 Avignon, France

${ }^{\mathrm{b}}$ INRA, UR 0407 Pathologie Végétale, F-84000 Avignon, France

Short title: IN VITRO TOMATO FRUIT AND SUCROSE

${ }^{*}$ Corresponding author:

Philippe Bussières

Institut National de la Recherche Agronomique

UR1115 Plantes et Systèmes de culture Horticoles, F-84000 Avignon, France

e-mail: Philippe.Bussieres@avignon.inra.fr 
Version définitive du manuscrit publié dans / Final version of the manuscript published in : In Vitro Cellular and Developmental Biology Plant, 2011, Online First, DOI: 10.1007/s11627-011-9378-z

\begin{abstract}
The effect of sap sucrose concentration on fruit expansion is poorly understood. We investigated the effects of sucrose concentration on growth of tomato fruits, detached from the plant after the cell multiplication phase. A semi-open device was built to grow detached fruits, where the fruit pedicel was immersed in a nutrient solution which was automatically replaced each day. About $22 \mathrm{~d}$ after anthesis, tomato fruits were harvested, disinfected in alcohol and placed in the device with a sterile nutrient solution containing 5\% sucrose. After about $1 \mathrm{wk}$, the sucrose concentration was either increased to $15 \%$ or maintained at $5 \%$. The fruit expansion rate decreased when the sucrose concentration was increased, and after about 1 wk. these fruits weighed less than those grown at 5\% sucrose. Although all the fruits in the device grew much less than those maintained on the plant, a high sap sucrose concentration applied to the excised fruits after the cell multiplication phase inhibited the expansion of tomato fruits. The device and method developed here will be useful for future studies of fruit growth.
\end{abstract}

Keywords: fruit growth; in vitro culture; sterile medium; sucrose; tomato fruit 
Version définitive du manuscrit publié dans / Final version of the manuscript published in : In Vitro Cellular and Developmental Biology Plant, 2011, Online First, DOI: 10.1007/s11627-011-9378-Z

\section{Introduction}

After water, sucrose is the principal constituent of the sap that enters the phloem of tomato fruits. Ho et al. (1987) estimated sucrose concentrations of $13 \%$ in case of young fruits of plants grown on nutrient solution at high-conductivity, and 3\% in case of mature fruits of plants grown at low-conductivity. Sucrose is the principal source of energy and materials for cell division and tissue growth in fruit and it supplies the hexoses whose concentration largely determines the quality of the fruit. However, the effect of sap sucrose concentration on fruit growth is poorly understood.

Changes in the source/sink ratio of assimilates in tomato, implemented by removing fruit or growing the plant in darkness (Hurd et al. 1979, Bohner and Bangerth 1988, Baldet et al. 2002, Bertin et al. 2002, Bertin 2005, Prudent et al. 2009), indicate that the fruit grow less when this ratio is smaller. The smallest expansions of fruit observed under these conditions are likely due to low sucrose concentrations in the sap. In addition, the amount of dry matter in the fruit is also lower when the fruit load is higher (Prudent et al. 2009).

It is generally thought that water enters the tomato fruit more slowly when the difference between the water potentials in the stem and in the fruit is small and/or when resistance to transport is high in the fruit. Therefore, lower osmotic potential in the stem, higher osmotic potential in the fruit, higher sap viscosity, and/or higher tissue resistance to deformation when water enters the fruit can lead to smaller fruit (Lee 1990, Bussières 1994 and 1995). Mitchell et al. (1991) showed that the difference between the water potential in the stem and the osmotic potential in the fruit is smaller when the water potential in the stem is lower. At the same time, the fruit is smaller and its dry matter content is greater. According to the data of Ho et al. (1987), the concentration of the sap entering the fruit is higher. Thus, because the water potential of a solution diminishes as its osmotic pressure increases, the fruit is expected to be smaller when the sucrose concentration is higher, because of the likely low difference between the water potential in the sap and the osmotic potential in the fruit, and because of the likely higher viscosity of the sap (sucrose solution viscosity increases from 1.14 to $1.59 \mathrm{MPa} \mathrm{s}$ as the concentration increases from $5 \%$ to $15 \%$ at $20^{\circ} \mathrm{C}$ ). Another possible reason is that thicker cell walls are expected when the proportion of dry matter is higher, making the tissue more resistant to deformation.

Thus, there is a contradiction between the hypothesis that a low fruit load encourages growth by increasing the sucrose concentration of the sap, and the hypothesis that a higher sucrose concentration discourages growth because water enters the fruit more slowly. This contradiction could be explained by supposing that within a lower range of sucrose concentration the sucrose is the limiting factor, while above this 


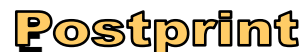

Version définitive du manuscrit publié dans / Final version of the manuscript published in : In Vitro Cellular and Developmental Biology Plant, 2011, Online First, DOI: 10.1007/s11627-011-9378-z

range excess sucrose is the limiting factor. A precise knowledge of the relationship between growth and sucrose concentration in the sap would be useful for understanding and optimizing the cultivation of fruit with the desired amounts of dry matter and sugars.

Studying the effect of sucrose concentration on fruit growth is not easy, mainly because the sucrose concentration in the sap is difficult to measure. Methods of sap sampling based on EDTA-enhanced exudation (King and Zeevaart 1974, Najla et al. 2010) are questionable, because the sampling process perturbs the plant. The aphid stylet technique (Barlow and McCully 1972) and analysis of aphid honeydew (Merrit 1996) are technically difficult. Accurate models for predicting the sucrose concentration remain ellusive. Further, the sucrose concentration and speed of exudation can vary depending on the sampling location within a plant (Merrit 1996). In addition, controlling the concentration of sucrose in the plant sap for quantitative experiments is also problematic.

Another approach to manage the sucrose concentration of the solution entering the fruit is to cultivate the fruit on a nutrient medium. The cultivation of detached tomatoes has been the object of numerous studies (Jansen and Bonner 1949, Nitsch 1951, Jansen 1953, Teitel et al. 1985, Geelen et al. 1987, Bohner and Bangerth 1988, Guan and Janes 1991). The sucrose concentrations used in semi-solid or liquid media were always less than or equal to $8 \%$, and in most cases ranged between $2 \%$ and $4 \%$. After $7 \mathrm{~d}$ of cultivation, Jansen (1953) observed that the diameters of fruit growing in the $4 \%$ solution were greater than those of fruit growing in the $2 \%$ solution. However, after $14 \mathrm{~d}$ there was no significant difference in fruit diameter using media containing $2 \%, 4 \%$, and $6 \%$ sucrose. Jansen reports that one fruit, cultivated in an $8 \%$ solution, was smaller than the others. Guan and Janes (1991) obtained fruit with a quantity of dry matter proportional to sucrose concentrations up to $8 \%$. Surprisingly, the effects of higher sucrose concentrations on tomato fruit development has not been reported.

However, wide variations in sucrose concentrations in plant tissues occur over the course of the day (Medina et al. 1993, Gholami et al. 2004, Najla et al. 2010). This seems to result from a reduction in water levels as the day progresses due to transpiration while the quantity of sucrose increases due to photosynthesis.

In preliminary experiments (Bussières et al. 2008), we studied the effect of sucrose concentration on the expansion of detached tomato fruits in nutrient solution, testing a wide range of sucrose concentrations ( $0 \%$ to $32 \%)$. The fruits were detached about $10 \mathrm{~d}$ after anthesis, placed in vitro and grew to the red fruit stage with their pedicel immersed in a nutrient solution. Although the nutrient solution was held in a closed container to maintain sterility, microbial contamination was observed in a number of replications. In non-contaminated samples, the 


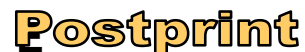

Version définitive du manuscrit publié dans / Final version of the manuscript published in : In Vitro Cellular and Developmental Biology Plant, 2011, Online First, DOI: 10.1007/s11627-011-9378-z

final diameter of the fruit increased with sucrose concentration up to about $5 \%$ but the diameter decreased with concentrations higher than $5 \%$ sucrose; there was almost no expansion with $32 \%$ sucrose. However, these experiments did not distinguish between the effect of sucrose concentration on cell multiplication at the beginning of growth (Bohner and Bangerth 1988, Bertin 2005) and the effect on cell expansion that occurs throughout growth. Similar results were obtained by Sasaki et al. (2005) with rice grains on detached ears, which were cultured on sucrose solutions. The mean grain weight increased with the sucrose concentration up to 5-7\%, whereas higher concentrations were inhibitory, possibly due to the low water potential.

Generally speaking, in vitro fruit culture requires that the tissue be sterilized and maintained aseptic under sterile conditions. When using fruits taken from plants cultivated in sterile surroundings or fruits treated with a disinfectant, an acceptable level of sterility can be obtained by using small, closed containers. However, maintaining sterility is more difficult where treatments are continuously altered during growth. Moreover, it is difficult to continually and precisely monitor fruit weight under these conditions, although this information might be useful. Fruits are often removed from culture at different times to determine growth characteristics (Teitel et al. 1985). However, it is necessary to repeat such experiments several times to account for variability in the rates of development, and it can be difficult to obtain an initial sample of fruits that are sufficiently similar. Although the diameter of a single fruit can be measured at various moments in its growth (Geelen et al. 1987), estimations of volume or weight from diameter measurements are imprecise.

To better study the effect of sucrose concentration on the expansion rate of fruit after the cell multiplication phase, we have developed a new device named "Casafruit" for cultivating detached fruits in a semi-open system. With this device and adequate disinfection procedures, it was possible to precisely observe the effect of a sudden increase in sucrose concentration from $5 \%$ to $15 \%$ on the weight of the fruit. In this paper, we describe the new device and show that a large increase in sucrose concentration inhibits the expansion of tomato fruit.

\section{Materials and Methods}

The Casafruit device. The Casafruit device (Fig. 1) consists of 4 identical cases, each with a number of accessories. Each case (Fig 1b) is a rectangular parallepiped with internal dimensions $53 \times 10 \times 10 \mathrm{~cm}$; the walls are made of acrylic material (Perspex Cast INC 000, LUCITE International France, Clairvaux-Les-Lacs, France) and are $1 \mathrm{~cm}$ thick. The support structure holds the case so that the square cross section is in a diagonal position. 
An internal plate $3 \mathrm{~cm}$ wide, also of Altuglas, is pierced with holes whose number and diameter are adapted to the expected final size of the fruit and pedicel. In the experiments described below, the plates had 8 holes $3 \mathrm{~mm}$ in diameter, although only 6 fruits were grown. The pedicel of the fruit passes through the hole and is immersed in the solution filling the volume underneath the plate (about $150 \mathrm{ml}$ ).

The solution is injected by a pump (NF10KPDC 12v, KNF Neuberger, Village-Neuf, France) with 0.11 $\min ^{-1}$ capacity and a solenoid valve (SCB262B24DC, ASCO-Numatics, Rueil Malmaison, France). The case is filled until the level of liquid reaches the position of an optical sensor (ELS-1100, GEMS Sensors \& Controls, Plainville, CT, USA). The case is emptied by gravity when another solenoid valve is opened.

The atmosphere can be renewed by injecting air or gas through a filter. In the experiments described below, we applied a air flow rate of about $41 \mathrm{~h}^{-1}$ lasting for $1 \mathrm{~h}, 4$ times per $\mathrm{d}$. Without this renewal, water condensation formed on the walls of the case.

The interior temperature of the cases is regulated by a water circuit in contact with a metal plate inside each case. The temperature of the water is regulated by a cryostat with a precision of $0.01^{\circ} \mathrm{C}(\mathrm{F} 6, \mathrm{HAAKE}$, Karlsruhe, Germany). The temperature sensor is inserted through a tube that enters one of the cases (so that it can be disconnected without opening the case). The other 3 cases have thermometers. The circuit includes 2 subcircuits, each 1 feeding 2 cases in series, such that the 2 pairs of cases can be maintained at the same temperature or different temperatures.

The nutrient solution (its composition is described below) was sterilized for $10-15$ min at $125-128^{\circ} \mathrm{C}$ and a pressure of 1.5-1.6 bars.

To limit variations in composition and the development of contaminants, the nutrient solution was changed every day. After removing the solution and before replacing it, the case was rinsed with diluted bleach ( $0.1 \%$ active chlorine solution). The process of emptying and rinsing the case takes only $1-2$ minutes; the chlorine rinse is allowed to run out as soon as its level reaches the sensor. In the experiments described below, as well as other experiments with young fruits cultivated to the red stage (over about $35 \mathrm{~d}$ ), no contamination was observed.

The system also includes a programmer (Millenium 3, CROUZET, Valence, France) that commands the cycle of removing the solution, rinsing the case, and pumping in fresh solution at selected dates and times.

The average weight of the fruits in each case can be obtained at any time during the experiment. The fruits along with the ensemble of equipment (the case, its supports and some parts of the accessories, hereafter simply referred to as a "case") are weighed using a screw jack resting on a scale, after removing the solution, 


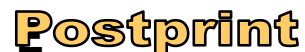

Version définitive du manuscrit publié dans / Final version of the manuscript published in : In Vitro Cellular and Developmental Biology Plant, 2011, Online First, DOI: 10.1007/s11627-011-9378-z

emptying the heating circuit and detaching the external accessories. The weight of the case having been determined previously, the average weight of a fruit with its pedicel and calyx is obtained. Comparisons between this estimated weight and the true mean weight of 1 fruit with its pedicel and calyx measured just after outgoing from the case showed that the possible error due to liquid traces left over the fruit, case and tube surfaces was small (Table 1). The weight of the fruit without calyx and pedicel at any time $t$ is estimated as the weight of the fruit with its calyx and pedicel at $t$ minus the pedicel and calyx weight at the trial end and plus the estimated increase in the pedicel and calyx weight between $t$ and the trial end. This increase is calculated by the observed regression between the fruit weight and the pedicel and calyx weight observed in a sample of the fruit population.

Experimental procedure. Trusses with at least 1 fruit approximately the desired size (the average fruit weight in each case was between 23 and $27 \mathrm{~g}$ ) were taken from tomato plants (cv. Levovil) cultivated in a greenhouse (CTIFL, Balandran, France). Based on observations of plants and trusses from the same crop, we estimated the post-anthesis age of the selected fruits to be about $22 \mathrm{~d}$. The trusses were cut from the plant at their point of insertion on the stem and immediately placed in a cooler to stop the flow of sap. Tissues arrived at the laboratory within $2-3 \mathrm{~h}$, and then were maintained at $5^{\circ} \mathrm{C}$ for another $2-3 \mathrm{~h}$. Fruits of the desired size were selected, generally 1 per truss. On each truss, the fruits farthest from the selected fruit were eliminated by cutting their pedicel, keeping the closest 2 or 3 fruits. The reduced trusses were dipped in $70 \%$ alcohol for $30-35 \mathrm{~s}$, and then rinsed 3 times for $5 \mathrm{~min}$ in sterile water. The pedicels of the selected fruit were then cut with a razor blade at their point of insertion on the principal axis of the truss. The whole operation took place under a sterile, laminar flow hood. The fruits were immediately placed in the cases, which had previously been cleaned with bleach and alcohol. Each case had 6 fruits. The cases were opened and closed as quickly as possible.

To estimate the relationship between the fruit weight and the weight of its pedicel and calyx, these variables were measured on 81 fruits, weighing between 0.1 and $51 \mathrm{~g}$, which were taken from plants or were detached fruits grown in the device in previous experiments.

Treatments. After placing the fruits in the case (6 per case), the nutrient solution was injected into the case. The nutrient solution contained $4.4 \mathrm{~g} \mathrm{l}^{-1}$ of Murshige and Skoog medium (MS 5519, Sigma-Aldrich, Saint Louis, MO, USA) and sucrose. In the treatment denoted T-5, 5\% sucrose was used throughout the entire trial period. In another treatment, denoted SC-5-15, the 5\% concentration was maintained for 7 to $9 \mathrm{~d}$, then elevated to $15 \%$. 
Version définitive du manuscrit publié dans / Final version of the manuscript published in : In Vitro Cellular and Developmental Biology Plant, 2011, Online First, DOI: 10.1007/s11627-011-9378-z

Five trials denoted 1 to 5 were made. In each trial, the 2 treatments were applied. The fruits used in the 2 treatments were taken from plants at the same time. Moreover, trials 2 and 3 were performed at the same time (using the 4 cases of the device), as were trials 4 and 5, thus using fruits taken from plants at the same time (Fig. 2). There were 5 replications of each treatment. In a first group of 3 replications (trials 1,4 and 5 ), the solution was changed about $7 \mathrm{~d}$ after the fruit was placed in vitro. In a second group of 2 replications (2 and 3$)$, the solution was changed after about $9 \mathrm{~d}$. The interior temperature of the cases was $25 \pm 1^{\circ} \mathrm{C}$.

During experiments, the cases were frequently weighed. At the end of each trial, the 6 fruits were removed from the case and weighed individually, with and without the pedicel and calyx. The dry matter content of the fruits was obtained by drying in an oven at 65-70 $\mathrm{C}$ for several $\mathrm{d}$.

Statistics. The relationships between experimental parameters and the characteristics of the fruit were determined using Student's $t$-test (for variables relative to the average fruit in a case) and the ANOVA method (for the final weights of fruit and pedicel and calyx which were measured for each fruit in a case). We used the SigmaStat software (Systat Software Inc., San Jose, CA, USA) for this analysis.

\section{Results}

No microbial contamination was visible during the experiments. The fruits were still green at the end of trials 1, 4 and 5 (about $36 \mathrm{~d}$ after anthesis), and they were either turning or red at the end of trials 2 and 3 (about $41 \mathrm{~d}$ after anthesis).

In each treatment, the mean deviation between the estimated and measured final weights of the fruit with its pedicel and calyx was small. This deviation was not significantly different between the 2 treatments T-5 and SC-5-15 (Table 2). The mean weight of the pedicel and calyx measured at the end of the experiment was also not significantly different between the 2 treatments. The regression between individual fruit weight $W(\mathrm{~g})$ and the weight $W_{\mathrm{p}+\mathrm{c}}(\mathrm{g})$ of its pedicel and calyx was $W=0.1553 \mathrm{e}^{0.03526 W_{\mathrm{p}+\mathrm{c}}}\left(R^{2}=0.53\right)$.

Just before the concentration of sucrose was increased in SC-5-15, the means of the estimated "average" weights of fruits were very similar in T-5 and SC-5-15 (Table 2).

As we mentioned previously, the initial weights of the fruits varied between 23 and $27 \mathrm{~g}$. To reduce the dispersion between the growth curves of average fruit weight observed in each case (Fig. 3a), which was probably partly due to slight differences in the initial fruit weights, each data point $W_{\mathrm{t}, \mathrm{i}}$ of a given trial was corrected as follows. Here, 'i' stands for the label of an individual trial (1, 2, 3, 4 or 5). 
First, we calculated the index $I$, equal to the ratio of a given fruit weight $W_{\mathrm{t}, \mathrm{i}}$ to the average fruit weight $W_{\mathrm{tc}, \mathrm{i}}$ observed at time $t_{\mathrm{c}}$ when the sucrose concentration was changed in the treatment SC-5-15 of the same trial $i$ :

$$
I=W_{\mathrm{t}, \mathrm{i}} / W_{\mathrm{tc}, \mathrm{i}}
$$

Next, in order to represent the changes in fruit weight, this index was multiplied by the mean, $W_{\mathrm{tc}}$, mean, of the average fruit weights obtained in the group of replications in which the sucrose concentration was increased in SC-5-15 at the same time $t_{\mathrm{c}, \mathrm{i}}$. As there were two groups of trials according to the value of $t_{\mathrm{c}}$ (approximately equal to 7 in the group constituted of the three trials 1,4 and 5, or to 9 in the group constituted of the two trials 2 and 3), the corrected fruit weight was.

$$
W_{\mathrm{t}, \mathrm{i}, \text { corrected }}=\left(W_{\mathrm{t}, \mathrm{i}} / W_{\mathrm{tc}, \mathrm{i}}\right) \times W_{\mathrm{tc}, \text { mean }} \quad \text { with } t_{\mathrm{c}} \text { equal to } 7 \text { or } 9
$$

In all trials, the fruit grew more slowly in SC-5-15 than in T-5 after the sucrose concentration was changed in SC-5-15. The regressions were calculated for each group of the 3 or 2 replications in each treatment before and after the change (Fig. 3b). Before the change, the slopes observed in T-5 and SC-5-15 were not significantly different whatever the group of trials. After the change, the slopes observed in SC-5-15 were significantly lower $(\mathrm{P}<0.01)$

The radial growth rate of the average fruit due to imported water, $F_{\mathrm{iw}},\left(\mathrm{g} \mathrm{cm}^{-2}\right.$ day $\left.^{-1}\right)$ (which is equal to the water import rate into the fruit $\left(\mathrm{g} \mathrm{day}^{-1}\right)$ per surface area unit of fruit estimated assuming the fruit to be a sphere with a density equal to 0.95 (Bussières 1993)) decreased (Fig. 4) with the fruit radius (cm), as observed previously (Bussières 1993). However, after the sucrose concentration increase, $F_{\text {iw }}$ decreased more rapidly in SC-5-15 than in T-5 in the same fruit radius range (Fig. 4).

The true and estimated weight increases of the average fruit at the end of the trials were significantly smaller in experiment SC-5-15 than in experiment T-5 (Table 2). Analysis of the variance in true individual fruit weights of the 6 fruits per replication measured after the fruits were removed from their cases indicated that the mean fruit weight in treatment SC-5-15 was significantly $(\mathrm{P}<0.001)$ lower than in treatment $\mathrm{T}-5$ while the analysis did not reveal any significant difference among trials nor a significant interaction between treatments and trials. The estimated increase in the fruit weight in SC-5-15 during the period where the sucrose concentration was $15 \%$ was only about half of that estimated in T-5 during the same period (Table 2). Although the amount of fruit dry matter was almost identical, the average proportion of dry matter in the SC-5-15 fruits was $13 \%$ greater than that of the T-5 fruits, but this difference was not statistically significant $(\mathrm{P}<0.130$; Table<smiles>[124IH]</smiles> 
Version définitive du manuscrit publié dans / Final version of the manuscript published in : In Vitro Cellular and Developmental Biology Plant, 2011, Online First, DOI: 10.1007/s11627-011-9378-z

\section{Discussion}

The present results confirmed that a high sap sucrose concentration inhibits the expansion of detached tomato fruits during the phase of growth dominated by cell expansion. Because the rate of fruit expansion diminished almost immediately after the sucrose concentration was augmented, it is highly unlikely that the observed effect was due to increased tissue deformation resistance brought on by thickening walls. It was more likely due to the decreased gradient in the water potential and the increased viscosity of the sap which are expected from the decreased osmotic potential of the nutrient solution.

In these trials, the estimated water importation rate per unit surface area of the fruit diminished as the fruit radius increased. A similar variation was found (Bussières 1993) for fruits growing on the plant (Ho et al. 1987), in which the water potential at the entry point to the fruit, the osmotic potential of the fruit and the sap viscosity were thought to be constant, and this variation was explained by a biophysical model involving these parameters (Bussières 1994, 1995). Here, the slope of the curve shown in Fig. 4 was altered during the fruit expansion by changing the water potential at the entry point, and likely the osmotic potential into fruit and sap viscosity. Also in the trials from Ho et al. (1987) with different nutrient solution salinities, the estimated slope was greater at lower estimated water potential at the entry point.

Future research should be able to separate the contributions of the water potential gradient and sap viscosity to the growth rate by repeating the experiments at different temperatures and using solutions having different osmotic potentials obtained by components chemically inactive for the fruit.

As is generally observed with in vitro fruit culture, even the largest specimens were much smaller (39 g) than fruits grown on the plant in the greenhouse (about $120 \mathrm{~g}$ ). However, the dry matter content (4.9\%) of the in vitro fruits was comparable to that of fruits grown on the plant (Bertin et al. 2009). Although only a short growth period was evaluated in these trials, the average proportion of dry matter obtained in treatment SC-5-15 was higher than that observed in treatment T-5, albeit only at the $13 \%$ significance level. However, the amount of dry matter accumulated by the fruit was almost the same. Ho et al. (1987) observed similar behavior in tomato fruits grown on a high salinity nutrient solution. Thus, the most important effect of increasing the sucrose concentration was probably to decrease the quantity of water entering the fruit. As the amount of dry matter entering the fruit was constant, it would appear that the lesser amount of sap entering the fruit is offset by the increased sucrose concentration of the nutrient solution. This relation needs to be verified precisely by taking 


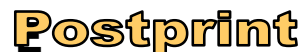

Version définitive du manuscrit publié dans / Final version of the manuscript published in : In Vitro Cellular and Developmental Biology Plant, 2011, Online First, DOI: 10.1007/s11627-011-9378-z

into account respiratory losses, which should be possible by measuring the volume and carbon dioxide concentration of gas escaping from the case.

When Guan and Janes (1991) removed fruits from the plant $6 \mathrm{~d}$ after anthesis and cultivated for $42 \mathrm{~d}$ in a nutrient solution, the final weights of the fruits were proportional to the sucrose concentration, for concentrations of $2 \%, 4 \%, 6 \%$ and $8 \%$. Their result could be due to the effect of sucrose concentration during the cellular multiplication phase, and/or to the existence of a threshold (one greater than $8 \%$ ) above which the effect of sucrose concentration changes from positive to negative. Similar to the results reported here, Sasaki et al. (2005) observed an inhibitory effect of high sucrose concentrations $(=7-8)$ on the weight of rice grains of detached ears cultured on nutrient solution and suggested that this was largely due to the low water potential.

As the sucrose concentration in the plant varies over the course of the day, low growth rates, similar to those observed here, may also occur naturally in the plant as the sucrose concentration increases, but on a shorter time scale and especially at the end of the day.

In future research, it will be also necessary to study the effects of sucrose concentration during the first phase of fruit growth, when cellular multiplication is dominant. Studying the effects of sucrose concentrations within the range of $8-15 \%$ and of variations over the course of a day will be also important.

The device and the method used in this research which allowed to grow fruit in vitro and without microbial contamination appear perfectly adapted to these types of studies, when it is important to manage the nutrient solution and to assess the fruit weight changes over the growth period.

\section{Acknowledgements}

The authors thank D Grassely and M Tisiot (Centre Technique Interprofessionnel des Fruits et Légumes, Balandran, France), who provided the fruits for this experiment. This work was supported by grants (Innovating Project) of the Environment and Agronomy Department of INRA, Paris, France.

\section{References}

Baldet P, Devaux C, Chevalier C, Brouquisse R, Just D, Raymond P (2002) Contrasted responses to carbohydrate limitation in tomato fruit at two stages of development. Plant Cell Environ 25: 1639-1649 


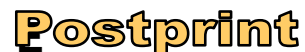

Version définitive du manuscrit publié dans / Final version of the manuscript published in : In Vitro Cellular and Developmental Biology Plant, 2011, Online First, DOI: 10.1007/s11627-011-9378-z

Barlow CA, McCully ME (1972) The ruby laser as an instrument for cutting the stylets of feeding aphids. Can J Zool 50: 1497-1498

Bertin N (2005) Analysis of the tomato fruit growth response to temperature and plant fruit load in relation to cell division, cell expansion and DNA endoreduplication. Ann Bot 95: 439-447

Bertin N, Causse M, Brunel B, Tricon D, Génard M (2009) Identification of growth processes involved in QTLs for tomato fruit size and composition. J Exp Bot 60: 237-248

Bertin N, Gautier H, Roche C (2002) Number of cells in tomato fruit depending on fruit position and source-sink balance during plant development. Plant Growth Regul 36: 105-112

Bohner J, Bangerth F (1988) Effects of fruit set sequence and defoliation on cell number, cell size and hormone levels of tomato fruits (Lycopersicon esculentum Mill.) within a truss. Plant Growth Regul 7: 141-155

Bussières P (1993) Potential dry matter and water import rates in tomato fruit in relationship to fruit size. Ann Bot 72: 63-72

Bussières P (1994) Water import rate in tomato fruit: a resistance model. Ann Bot 73: 75-82

Bussières P (1995) Dry matter and water import rates in the tomato fruit: a model incorporating the changes in sap viscosity and osmotic potential with temperature. Ann Bot 75: 469-476

Bussières P, Bertin N, Nasri R, Valat L, Sallanon H (2008) Detached tomato fruit grown on various saccharose solutions and comparison with fruit grown on plant. Poster. First Symposium in Horticulture in Europe. Vienna, Austria

Geelen TAM, Varga A, Bruinsma J (1987) Cell division and elongation in the exocarp of tomato fruits grown in systems in vitro and on the vine. J Plant Physiol 130: 343-349

12

Comment citer ce document : 


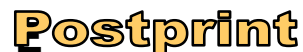

Version définitive du manuscrit publié dans / Final version of the manuscript published in : In Vitro Cellular and Developmental Biology Plant, 2011, Online First, DOI: 10.1007/s11627-011-9378-z

Gholami M, Coombe BG, Robinson SR (2004) Grapevine phloem sap analysis: 1- sucrose, amino acids, potassium concentrations, seasonal and diurnal patterns. Acta Horticulturae 640: 143-153

Guan HP, Janes HW (1991) Light regulation of sink metabolism in tomato fruit. 1 Growth and sugar accumulation. Plant Physiol 96: 916-921

Ho LC, Grange RI, Picken AJ (1987) An analysis of the accumulation of water and dry matter in tomato fruit. Plant Cell Environ 10: 157-162

Hurd RG, Gay AP, Mountifield AC (1979) The effect of partial flower removal on the relation between root, shoot and fruit growth in the indeterminate tomato. Ann Bot 93: 77-89

Jansen LL (1953) Studies in fruit growth and in vernalization. Thesis, California Institute of Technology, Pasadena, CA, USA (http://resolver.caltech.edu/CaltechETD:etd-04232003-161523)

Jansen LL, Bonner J (1949) Development of fruits from excised flowers in sterile culture. Am J Bot 36: 826

King RW, Zeevaart JAD (1974) Enhancement of phloem exudation from cut petioles by chelating agents. Plant Physiol 53: 96-103

Lee DR (1990) A unidirectional water flux model of fruit growth. Can J Bot 68: 1286-1290

Medina E, Popp M, Olivares E, Janett HP, Lüttge U (1993) Daily fluctuations of titrable acidity, content of organic acids (malate and citrate) and soluble sugars of varieties and wild relatives of Ananas comosus L. growing under natural tropical conditions. Plant Cell Environ 15: 55-63

Merrit SZ (1996) Within-plant variation in concentrations of amino acids, sugar, and sinigrin in phloem sap of black mustard, Brassica nigra (L.) Koch (cruciferae). J Chem Ecol 22: 1133-1145

Mitchell JC, Shennan C, Grattan SR (1991) Developmental changes in tomato fruit composition in response to 


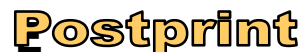

Version définitive du manuscrit publié dans / Final version of the manuscript published in : In Vitro Cellular and Developmental Biology Plant, 2011, Online First, DOI: 10.1007/s11627-011-9378-z

water deficit and salinity. Physiol Plant 83: 177-185

Najla S, Vercambre G, Génard M (2010) Improvement of the enhanced phloem exudation technique to estimate phloem concentration and turgor pressure in tomato. Plant Sci 179: 316-324

Nitsch JP (1951) Growth and development in vitro of excised ovaries. Am J Bot 38: 566-577

Prudent M, Causse M, Génard M, Tripodi P, Grandillo S, Bertin N (2009) Genetic and physiological analysis of tomato fruit weight and composition: influence of carbon availability on QTL detection. J Exp Bot 60: 923937

Sasaki H, Edo E, Uehara N, Ishimaru T, Kawamitsu Y, Shihoko S, Ueda D, Ohsugi R (2005) Effect of sucrose on activity of starch synthesis enzymes in rice ears in culture. Physiol Plant 124: 301-310

Teitel DC, Arad S, Birnbaum E, Mizrahi Y (1985) Growth and development of tomato fruits in vivo and in vitro. Plant Growth Regul 3: 179-189

\section{Figure Legends}

Fig. 1. The Casafruit device, with 4 identical cases (a). Perspective view (b) and longitudinal section (c) of a case.

C: connector; V: solenoid valve; F: filter; LS: level sensor; P: pump; R: faucet; TS: temperature sensor, S: nutrient solution, J: active chlorine solution.

Fig. 2. Description of the treatments. Five trials were made from 19 June to 10 August 2009. In each trial, 2 treatments were applied: T-5 (sucrose concentration maintained at 5\%) and SC-5-15 (sucrose concentration at $5 \%$ during the 7 or 9 first $d$ and then raised at 15\%). Each treatment was applied in 1 of the 4 cases (numbered from 1 to 4 ) of the device. The gray parts indicate the cases and the periods where sucrose concentration was equal to $15 \%$. Note that from 19 June to 3 July, cases 3 and 4 were not used with these 
Version définitive du manuscrit publié dans / Final version of the manuscript published in : In Vitro Cellular and Developmental Biology Plant, 2011, Online First, DOI: 10.1007/s11627-011-9378-z

treatments.

Fig. 3. Effect of increasing the sucrose concentration on estimated (a) and corrected (b) fruit weights over the duration of the trials with detached fruits grown with a nutrient solution in the Casafruit device. The arrows indicate the moment $t_{\mathrm{c}}$ at which the sucrose concentration was increased in SC-5-15. The full line arrows indicate $t_{\mathrm{c}}$ for trials $1(\Delta$ and $\boldsymbol{\Delta}), 4(\diamond$ and $\diamond)$ and $5(\circ$ and $\bullet)$ with solid lines; the dashed line arrow indicates $t_{\mathrm{c}}$ for trials $2(\square$ and $\boldsymbol{\square})$ and $3(\circ$ and $\bullet$ ) with dotted lines. In (a), the empty symbols refer to treatment T-5 in which the concentration was equal to 5\% throughout the period; the filled symbols refer to treatment SC-5-15 where the concentration was increased from $5 \%$ to $15 \%$ at $t_{\mathrm{c}}$. Because the mean weights of the fruits at $t_{\mathrm{c}}$ varied among the trials, the estimated weight of the average fruit in a given trial at time $t$ was corrected according to Equation 2. These corrected weights are shown in (b); the symbols refer to trials 1, 4 and 5 together (squares) and to trials 2 and 3 together (circles); the empty symbols refer to treatment T5, the grey symbols refer to the first phase of treatment SC-5-15 and the full symbols refer to the second phase of treatment SC-5-15; the regressions are given for each group of trials, each treatment and before or after time $t_{\mathrm{c}}$ where sucrose concentration was increased (for the group of trials 1,4 and 5, the regression lines obtained before $t_{\mathrm{c}}$ in T-5 and in SC-5-15 are overlapped).

Fig. 4. Radial growth rate of the fruit due to imported water $\left(F_{\mathrm{IW}}\right)$ as a function of fruit radius, in treatments $\mathrm{T}-5$ (+ symbols) and SC-5-15 ( $\mathrm{O}$ symbols before increasing the concentration, $\bullet$ symbols after). The thick line is the diagonal linear regression obtained for the 5 replications of treatment SC-5-15 after increasing the sucrose concentration of the nutrient solution. The thin line is the regression obtained for the 5 replications of treatment T-5 and data from treatment SC-5-15 before increasing the sucrose concentration of the nutrient solution. The values of $F_{\text {IW }}$ were calculated using the method described by Bussières (1993), but assuming no transpiration losses. The density of the fruit was assumed to be 0.95 , and the dry matter content was assumed to be constant and equal to $5 \%$. 
Version définitive du manuscrit publié dans / Final version of the manuscript published in : In Vitro Cellular and Developmental Biology Plant, 2011, Online First, DOI: 10.1007/s11627-011-9378-z

Table 1. Comparison of true and estimated fruit weights at the end of a preliminary experiment using the new device. Each case held eight fruits.

\begin{tabular}{ccccc}
\hline & Case 1 & Case 2 & Case 3 & Case 4 \\
\hline Estimated weight $(\mathrm{g})$ & 5.83 & 5.44 & 7.65 & 4.12 \\
Deviation from the true value $(\mathrm{g})$ & 0.08 & 0.10 & 0.28 & 0.07 \\
\hline
\end{tabular}

Table 2. Means and standard deviations (in parentheses) of various properties, obtained over five replications of treatments T-5 and SC-5-15 (the quantity and proportion of dry matter in the fruit were measured in only three replications). The treatment $\mathrm{T}-5$ held the sucrose concentration constant at 5\%. The treatment SC-5-15 maintained a 5\% concentration for 7-9 days, then increased it to $15 \%$ and held it constant thereafter. For each replication, the data were averaged over the six fruits in the case. The last column indicates the probability, according to Student's $t$-test or from analysis of variance (case indicated between parenthesis), that a difference between the means at least as large as the observed difference could have arisen from the same underlying distribution by chance.

\begin{tabular}{|c|c|c|c|c|}
\hline $\begin{array}{l}\text { Sucrose concentration in the nutrient } \\
\text { solution }\end{array}$ & $\mathrm{T}-5$ & SC-5-15 & $\begin{array}{l}\text { Difference } \\
\text { relative to } \\
\mathrm{T}-5(\%)\end{array}$ & Probability \\
\hline Initial weight of the fruit (g) & $25.39(0.45)$ & $24.49(0.96)$ & 4 & 0.092 \\
\hline $\begin{array}{l}\text { Deviation between the estimated weight of } \\
\text { the fruit, with its pedicel and calyx, in } \\
\text { place in the cases at the end of the trials, } \\
\text { and the true values measured when the } \\
\text { fruit is taken out (g) }\end{array}$ & $0.63(0.43)$ & $0.62(0.41)$ & 3 & 0.953 \\
\hline $\begin{array}{l}\text { Weight of the pedicel and calyx at the end } \\
\text { of the trials }(\mathrm{g})\end{array}$ & $0.70(0.06)$ & $0.64(0.07)$ & 9 & $(0.160)$ \\
\hline $\begin{array}{l}\text { Estimated weight of the fruit at the time the } \\
\text { sucrose concentration changes }(\mathrm{g})\end{array}$ & $32.26(1.44)$ & $31.63(0.68)$ & 2 & 0.400 \\
\hline $\begin{array}{l}\text { Estimated weight of the fruit at the end of } \\
\text { the trials }(\mathrm{g})\end{array}$ & $37.08(1.92)$ & $34.08(0.50)$ & 8 & 0.009 \\
\hline $\begin{array}{l}\text { Measured weight of the fruit taken out of } \\
\text { the case at the end of the trials }(\mathrm{g})\end{array}$ & $36.45(2.01)$ & $33.46(0.35)$ & 8 & $(0.001)$ \\
\hline $\begin{array}{l}\text { Estimated increase in the fruit weight } \\
\text { during the period when treatment SC-5-15 } \\
\text { used a sucrose concentration of } 15 \%(\mathrm{~g})\end{array}$ & $4.82(1.05)$ & $2.45(0.42)$ & 49 & 0.002 \\
\hline $\begin{array}{l}\text { Quantity of dry matter in the fruit at the } \\
\text { end of the trials }(\mathrm{g})\end{array}$ & $1.87(0.17)$ & $1.90(0.17)$ & 2 & 0.806 \\
\hline $\begin{array}{l}\text { Proportion of dry matter in the fruit at the } \\
\text { end of the trials }(\%)\end{array}$ & $4.93(0.34)$ & $5.58(0.48)$ & 13 & 0.130 \\
\hline
\end{tabular}




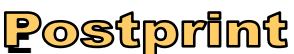

Version définitive du manuscrit publié dans / Final version of the manuscript published in : In Vitro Cellular and Developmental Biology Plant, 2011, Online First, DOI: 10.1007/s11627-011-9378-z
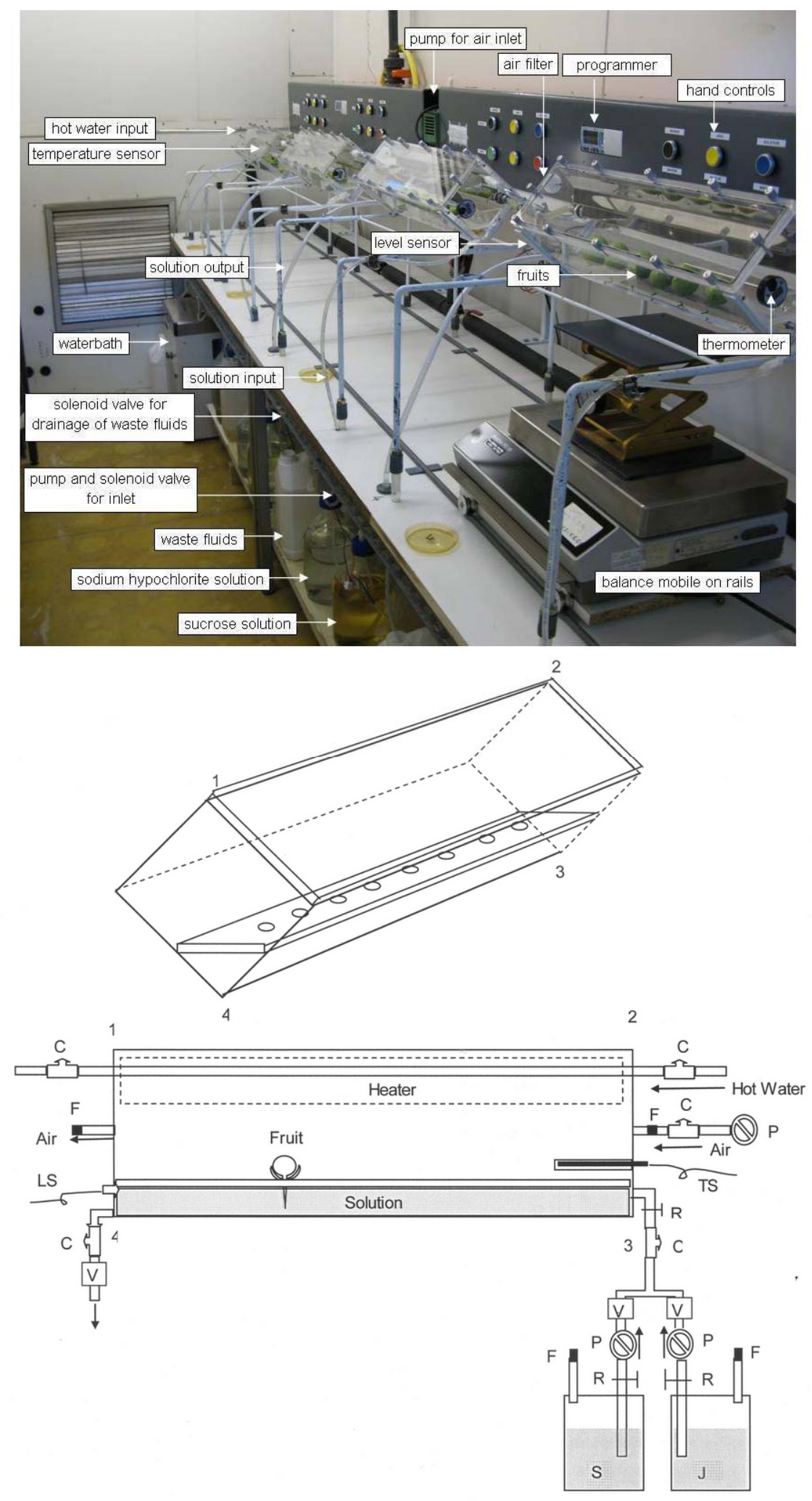
Version définitive du manuscrit publié dans / Final version of the manuscript published in : In Vitro Cellular and Developmental Biology Plant, 2011, Online First, DOI: 10.1007/s11627-011-9378-z

Trial 1

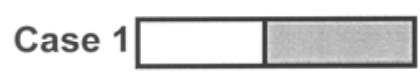

Case 2

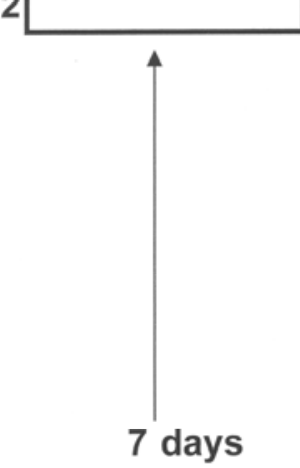

Trial 2

Case 1

Case 2

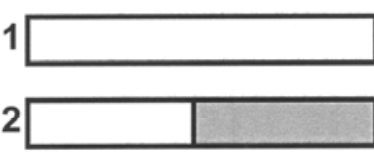

Trial 3

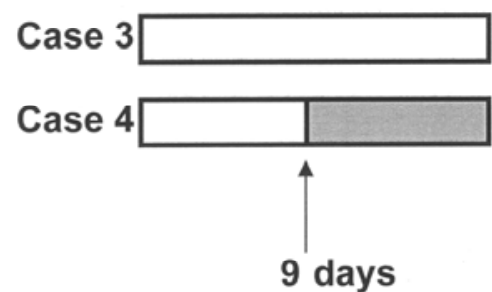

9 days
Trial 4

Case 1

Case 2

Trial 5

Case 3

Case 4

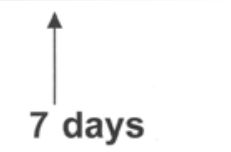

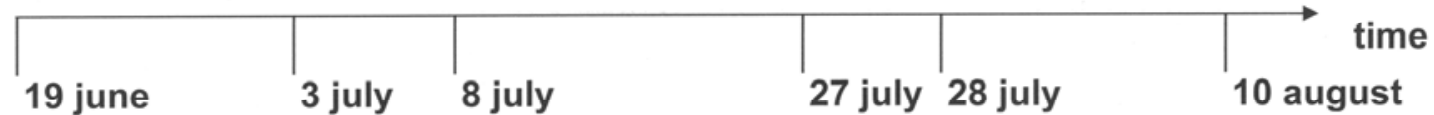


Version définitive du manuscrit publié dans / Final version of the manuscript published in : In Vitro Cellular and Developmental Biology Plant, 2011, Online First, DOI: 10.1007/s11627-011-9378-z
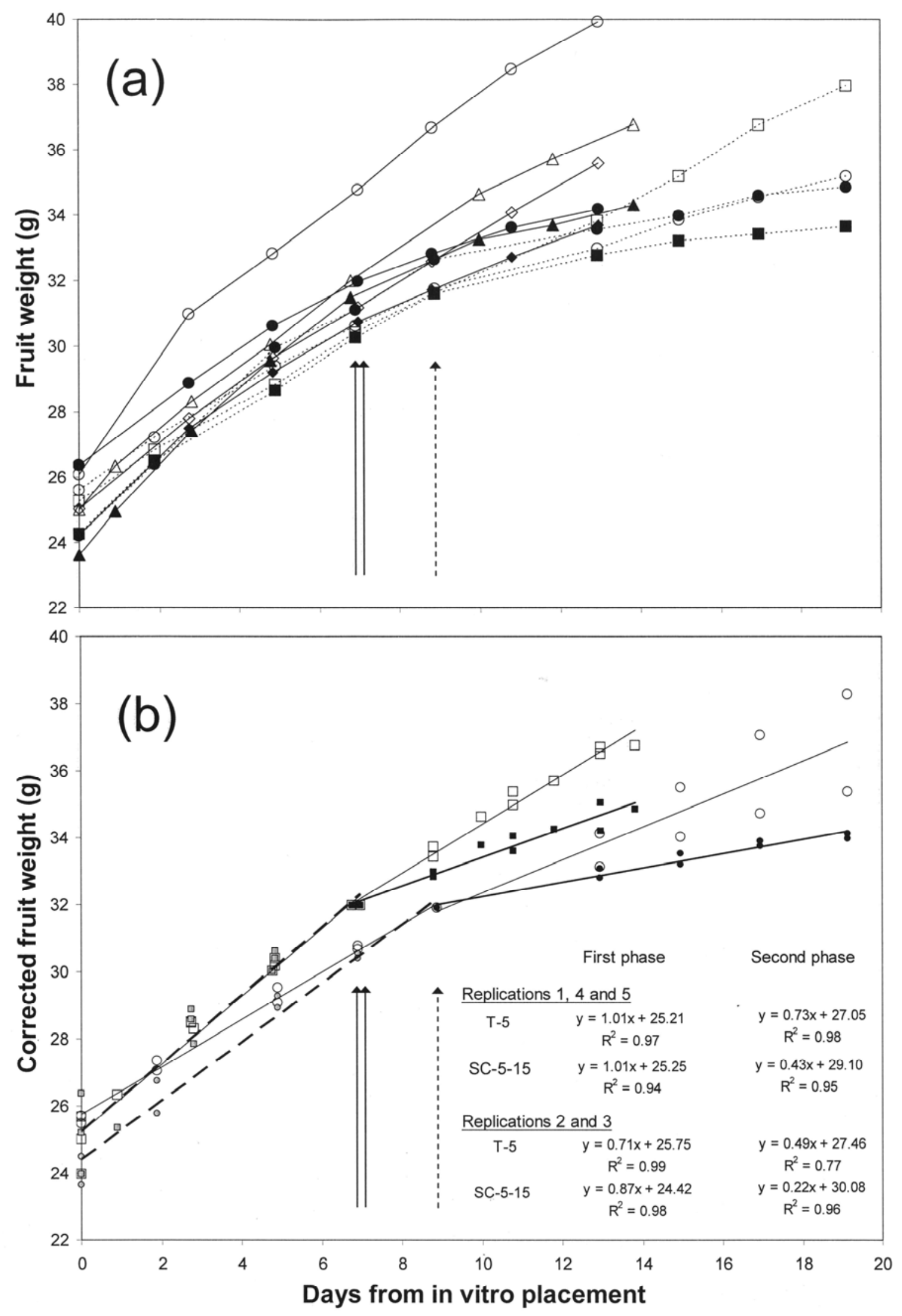


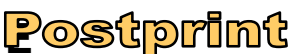

Version définitive du manuscrit publié dans / Final version of the manuscript published in : In Vitro Cellular and Developmental Biology Plant, 2011, Online First, DOI: 10.1007/s11627-011-9378-z

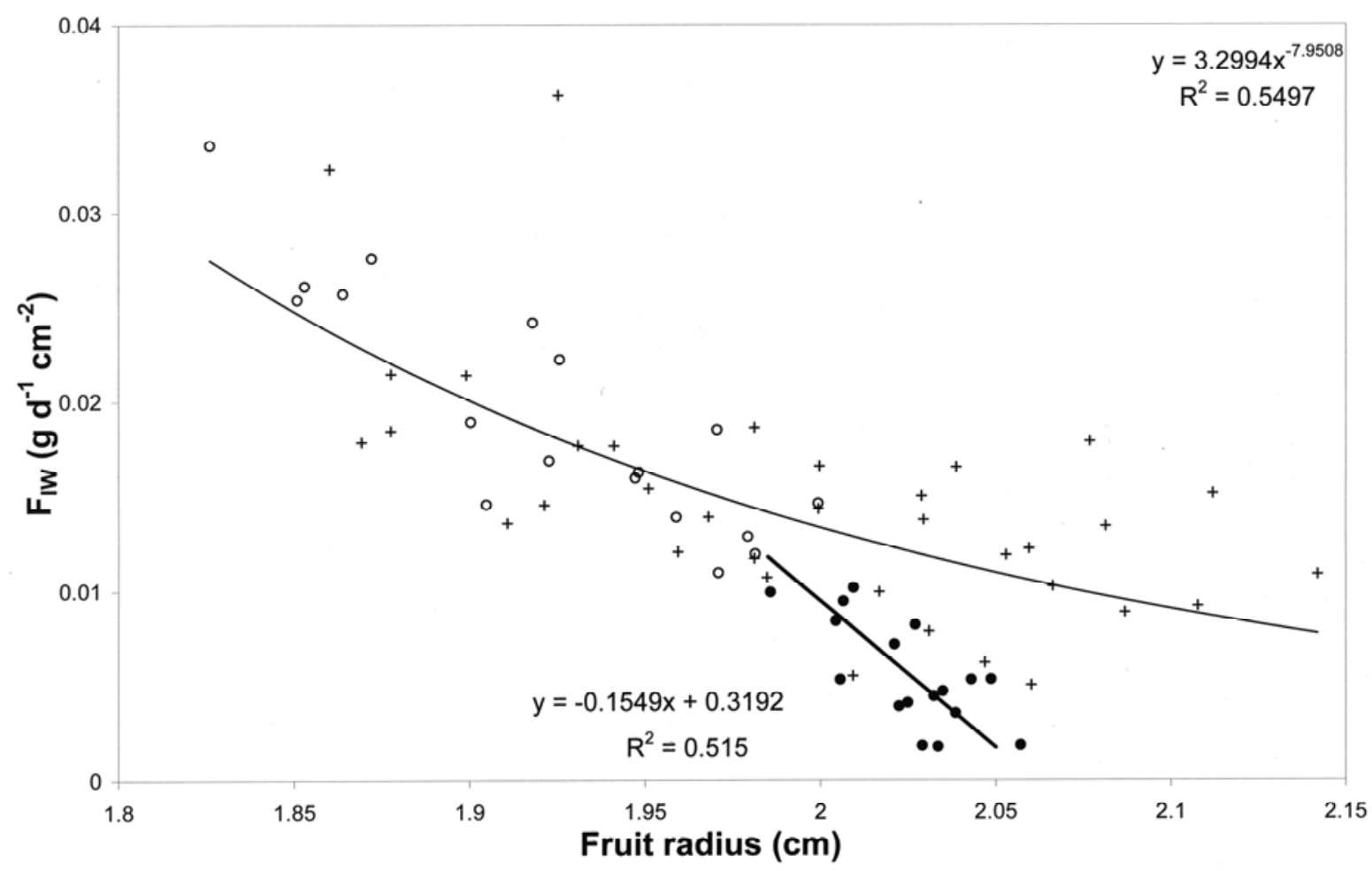

